\title{
IMPROVING RESEARCH ON INTERNATIONAL NEW VENTURES
}

Renato Souza Santos ${ }^{1}$

Pablo Leão ${ }^{2}$

Larissa Pacheco ${ }^{3}$

\footnotetext{
${ }^{1}$ Administração de Empresas / EAESP / Fundação Getulio Vargas

${ }^{2}$ Fundação Getúlio Vargas/EAESP

${ }^{3}$ Escola de Administração de Empresas de São Paulo / FGV-EAESP / Escola de Administração de Empresas de São Paulo
} 


\section{IMPROVING RESEARCH ON INTERNATIONAL NEW VENTURES}

Abstract: Different patterns of internationalization of new ventures have been questioning classical international business theories in the last couple decades. In this manuscript, we delve into the rapid internationalization approaches to provide a comprehensive and contemporary literature review on the most recent empirical research on international new ventures, as well as to document thoroughly the discrepancies and dissonances in the literature. By doing so we contribute with the field by presenting propositions which were drawn from a systematized analysis of 35 articles which summed a total of 167 case studies regarding international new ventures. We then integrated the literature and developed a set of suggestions to be included in future research along with recommendations regarding the rigor and detailing when analyzing an international new venture.

Keywords: international entrepreneurship; international new ventures; rapid internationalization.

\section{Introduction}

Internationalization of firms is a topic widely explored and the first theories date from the 1950's. However, a new pattern of internationalization of small and medium size firms have been calling attention of researchers and practitioners since 1993, when Rennie's seminal article coined the term "born-global firms". The term, as stated by the author, refers to the phenomenon of small and medium size companies that export, on average, two years after their inception, which corresponds to the biggest share of their total sales.

Oviatt and McDougall (1994) re-signified this term and brought attention to International New Ventures (INVs), combining entrepreneurship theories to explain these new business models. For the authors, INVs are businesses that, from their foundation, seek to derive significant competitive advantage from the use of resources and the sale of outputs in multiple countries. In general, the entrepreneurs are internationally experienced and able to link resources derived from multiple countries to meet the demand of international markets.

Further research explored the rapid internationalization process and other terms were associated to it, with few conceptual differences among them: micro-multinationals, global firms, global start-up, and so on. The contrariety about this concept is not only within the nomenclature, but is also found in the basic aspects that define an INV. The current literature extensively disagrees about the time of inception, relevance of international sales and presence in different markets (McDougall 1989; Knight \& Cavusgil 1996; Knight et al. 2004; Mort \& Weerawardena 2006; Rasmussen \& Madsen 2002; Rasmussen et al. 2001; Chetty and Campbell-Hunt 2004; Gabrielsson et al. 2004; Gabrielsson 2005).

Edmondson and McManus (2007) suggest that nascent theories, such as the one under scrutiny, demand qualitative aiming to identify patterns, to develop insights about a novel phenomenon and identifying gaps in existing theory. Therefore, qualitative methodologies such as case studies can serve this research topic for allowing to focus on understanding the dynamics present in a single setting (Eisenhardt, 1989) and contributing to theory development as this intimate contact
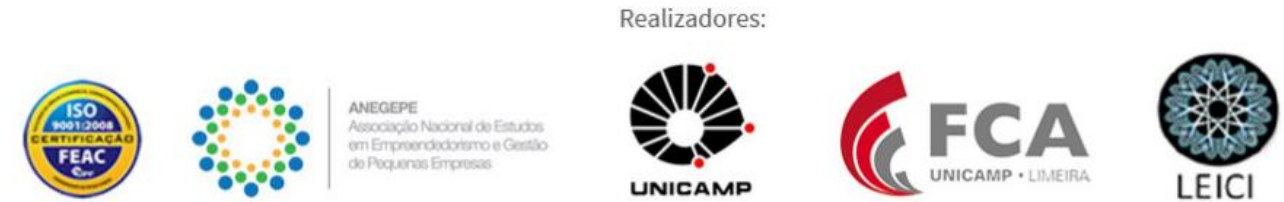
with empirical reality allows developing testable, relevant, and valid theories (Glaser \& Strauss, 1967).

Therefore, the aim of this article is twofold: first, to provide a comprehensive and contemporary literature review on the most recent empirical research on INVs, as well as to document thoroughly the discrepancies and dissonances in the literature, and second, to propose paths which can lead to the concept development and maturity.

It should be emphasized that the analyses and results of this article will be important to foment a holistic and integrated vision of theoretical and practical aspects on the available knowledge related to INVs. Therefore, the article is organized in five sections: the first comprises this introduction; the second presents the theory upon which this article relies on; the third explores the methodology to meet all settled objectives; the fourth part comprises the results obtained based in the systematic literature review. The final section presents the conclusions.

\section{Theoretical Background}

Previous research on international business have suggested that the internationalization process of the firms can be defined as a gradual commitment to the foreign market, as a function of knowledge acquired and cultural distance (Johanson \& Vahlne, 1977, 1990). However, since Rennie coined the term "born-global" firms in 1993 and Oviatt \& McDougall (1994) defined the types of INVs, this process has been questioned and has been promoted an intersectional movement between IB and Entrepreneurship.

From several issues researched on this recent topic, as well explored by Walch and Wehrmann (2014), Oviatt \& McDougall (1994) focused on exploring the rapid internationalization of small firms, defining them as INVs. These firms are already engaged in the international market from or near their inception (Knight \& Cavusgil, 2005, 2004, 1996; Rennie, 1993; Oviatt \& McDougall 1994) and they are "expected to exhibit compressed internationalization stages in a relatively short time span" (Hashai \& Almor, 2004, p.15).

Although the literature is quite diverse, a broad definition commonly used is the one proposed by Oviatt and McDougall (1994) - "a business organization that, from inception, seeks to derive significant competitive advantage from the use of resources and the sale of outputs in multiple countries". Despite meeting the authors goal in describing the phenomena, this definition fails to provide a clearer concept of the term regarding its operationalization, since the authors do not set any boundaries for classification (Badera \& Mazzarola, 2009).

Therefore, the classical literature established broad definitions which is the prevailing logic when constructing a theory, since the concept is yet to be tested with empirical researches (Whetten, 1989). With the expansion of the field, INVs have been typified differently across the literature and many concepts derived from that, such as born global (Rennie, 1993), micro multinationals (mMNE) (Dimitratos et al., 2014). and global start-ups (Mathews, 2006).

However, those concepts are quite similar and might lead to a confusing operationalization when applied it to different contexts. From the analysis of the recent literature, no consensus was found concerning the definition and operationalization of the concepts and those aspects deserve a

Organizadores:

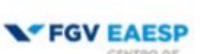

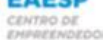

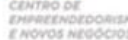

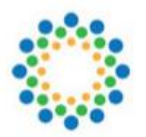

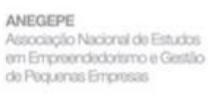

\section{Realizadores:}
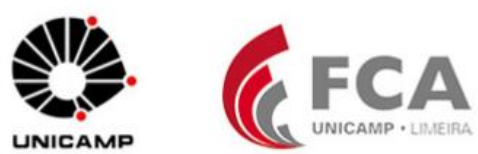

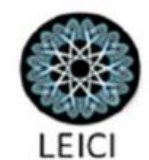


thorough analysis. Authors in the literature established different criteria for characterizing the types of INVs, which generates a wide range of possibilities and measures of the phenomena.

In general, authors consider a set of attributes upon which one can frame a case to be studied. In this matter, Dib et al. (2010) identified some features for born global firms, such as the internationalization pace, which can vary from 2 years (Moen, 2002) up to 15 years (Gabrielsson et al., 2014); the relevance of the international activity (mainly exports) in total sales - varying from at least 5\% percent (McDougall, 1989) to a minimum of 25\% (Knight \& Cavusgil, 2004); and the geographical scope of the operations, which for Sharma and Blomstermo (2003) means the presence of the new venture in one or few international markets, while for Gabrielsson et al. (2004) the presence must be in various regions of the world. As one can perceive the criteria range are broad and the terms applied in this classification attempt, such as, "few" and "various" are very subjective.

Oviatt \& McDougall (1994) states that the global start-up's internationalize through many activities coordinated across several countries. Coviello (2015) suggests that this type of INV differs from born-global firms since the first usually will capture multiple and global value chain activities very close to birth, and the latter will concentrate efforts on exports activity. However, no specific indicators are suggested to categorize firms in such definition.

Different from the aforementioned subtypes, the mMNE is a "small-and medium-sized firm that controls and manages value-added activities through constellation and investment modes in more than one country" (Dimitratos et al., 2003, p.165). mMNEs rather have higher resource commitment: it may not own foreign assets, but it may control important foreign assets (Dimitratos et al., 2014). For the authors, those ventures could be classified as network seekers, market hunters, flexibility pursuers, resource trackers, global-market chasers, learning seekers, and competition players.

As aforementioned, the concepts discussed present several similarities and unclear boundaries, which makes hard to establish the features that differentiate them. This difficulty is reflected in the literature, where conceptual stretching is generating a disconnected application of all types of INVs. Welch, Rumyantseva and Hewerdine (2016) add to this discussion, affirming that certain theoretical movements end up generating possibilities for new classifications and, therefore, more categories with several other variances to fit all the possible cases in the IE literature. This brief analysis goes in hand with these authors' goal, that was not to fix the concept, but to open it up to new discussions. Notwithstanding, if in one side it can help generating cutting-edge research agenda on rapid internationalization, on the other side it narrows the possibilities for a conceptual convergence in the field.

\section{(Figure 1 goes about here)}

In the attempt to clarify how the field of research is organized, we developed a framework that is presented in Figure 1. Young businesses facing a resource-constraint scenario associated with a rapid internationalization process demanded a new theory, as it no longer complied with the existing incremental theories of internationalization (Johanson \& Vahlne, 1977). This phenomenon not only initiated new discussions on IB literature, but also opened the venues for connections with the Entrepreneurship field, generating a new research field, named International Entrepreneurship (Zander, McDougall-Covin, \& Rose, 2015). By navigating in the literature, to our understanding, born-global firms, micro multinationals and global start-ups are types of INVs, will singular
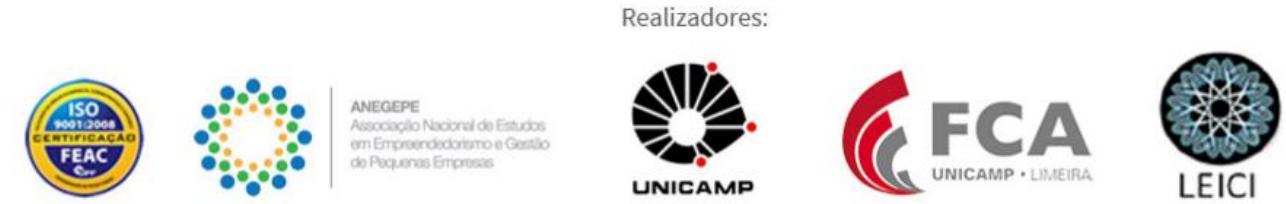
characteristic and whose the boundaries are still not clearly stated. As a field in constant evolution, resignification and subject to misinterpretations (Coviello, 2015), we critically analyze how it is been applied and discussed in empirical researches in the recent years. We further identify patterns and offer suggestions and research propositions that support convergence on the field based on the three types of INV's identified in the literature (Figure 1).

\section{Research Method}

The purpose of this article is to perform a systematic review of the literature analyzing the current knowledge and synthesize the results on the INVs phenomenon. Systematic reviews apply when the field of research is still emerging, consequently demanding consolidation efforts. Additionally, this methodology helps in developing conceptual models based on the recent theoretical discussions on the subject (Webster \& Watson, 2002).

Webster \& Watson (2002) suggest some steps to conduct a literature review:

- Identify relevant literature in the most relevant journals of a major area;

- Structure the review into conceptual tables to conduct a coherent analysis;

- Draw conclusions about the literature and elaborate propositions for the development of the research field.

For this literature review we selected only case studies once it is a method commonly used to develop emerging theories through inductive studies and to search for similarities and differences within and between cases (Eisenhardt \& Graebner, 2007).

\subsection{Data collection and categorization}

We conducted a research in Science Direct, Web of Science and EBSCO Host research bases in order to determine the impact of the studies reviewed in the sample (Webster \& Watson, 2002). We then used the following keywords: "born global", "new internationalizing firm", "new international venture", "international entrepreneurship", all combined with "case study". Despite the use of different concepts in our search, a further reading of the texts allowed us to assimilate that those were being used interchangeably. The period of research comprised articles published from 2010 to 2016, so we could explore the most recent works on the topic and advance upon the results of Badera and Mazzarola (2009).

Selection criteria were established to maintain a focused analysis. The first was the classification of the Journals where the articles were published, which should have an $\mathrm{H}$-index higher than 20 and a JCR above 1 - then, it was possible to select the best rated journals in the field of International Business (Webster \& Watson, 2002). Articles that were not completely available for download were excluded, along with conference papers. The last criterion was the approach of the case study(ies), which should have INVs as the focus.

Thereby, 244 articles were first selected. After applying each selection criteria, 56 articles were considered for reading and constructing the analysis. In one additional filter, other 21 articles were eliminated, which were duplicated or did not contribute to the analysis. Finally, a deep analysis of each case study explored in the 35 remaining articles allowed the selection of researches that

Organizadores:

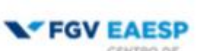

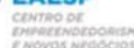
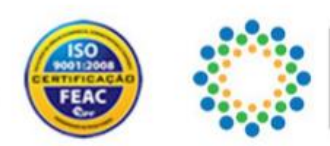

An
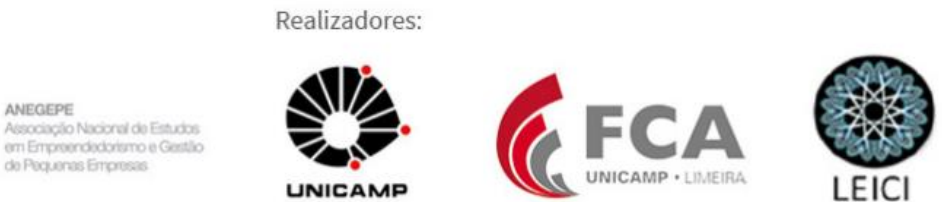
explored INVs in a manner consistent with the literature presented in the previous section, having the company as the unit of analysis.

Thus, the final sample of 35 articles comprised a total of 167 cases, which were deeply analyzed according to objective and subjective criteria related to the definitions of INVs previously discussed in Section 2. We analyzed the cases according to its attributes (Welch et al., 2016), contextual, and methodological characteristics of the articles.

\section{Results Presentation \\ 4.1 Overall analysis}

Our review of the articles commenced with an initial analysis of each publication, related to where and when it was published, country and sector under scrutiny, methodological approach for case studies, and focus of analysis. Most articles were published among 2011 and 2014, summing 26 articles from the total included in our sample. In the period researched, the production rhythm has dropped despite the relevance of the subject and the new characteristics, firms' trajectories, and subjects that are being connected to the topic (Dimitratos et al., 2016; Nummela et al. 2016).

Graphic 1 shows an analysis of the articles per journal and those with most articles represent top journals on the field of International Business: International Business Review (5) and Management International Review (4), followed by top journals on the field of International Entrepreneurship, such as Journal of Small Business and Enterprise Development (3) and Journal of International Entrepreneurship (3) - which confirms the interaction among research fields interested in studying several facets of INVs, such as mentioned by Zander et al. (2015).

\section{(Graphic 1 goes about here)}

Mostly, the authors use case studies as a tool to deeply comprehend the internationalization strategy (10) of INVs as well as to explore the importance of network relationships (8) for the establishment of such ventures and entrepreneurial features (6) that spur their inception and growth. These findings go in hand with what is shown in Graphic 1 - a spread movement of the concept usage in the Entrepreneurship literature. As suggested by Coviello (2015) many gains can be obtained through in-depth reasoning into the entrepreneur's logic and convictions.

In accordance to Dib et al. (2010), the results also demonstrated the lack of consensus on this field regarding the concepts usage. 19 articles used explicitly the Born-global concept, 6 used International Entrepreneurship, and other 10 used International New Ventures, all interchangeably adopted. It is important to highlight in this point of the analysis that those concepts differ if their seminal roots are considered. As defended by Zander et al. (2015), these organizational forms differ, mainly regarding their purpose (Coviello, 2015), and imprudent comparisons may weaken a coherent theoretical development of the field - almost generating a "conceptual chaos".

Most articles present multiple case studies, varying from 2 to 35 cases included in one article, and 6 papers opted for developing single case studies. Eisenhardt (1989) reinforces that, in a replication logic, multiple cases which confirm emergent relations enhance the validity of the relationship under analysis. Therefore, the major authors choice is justified in the sense to create enough support for the assumptions developed in their research and safeguard results generalization.
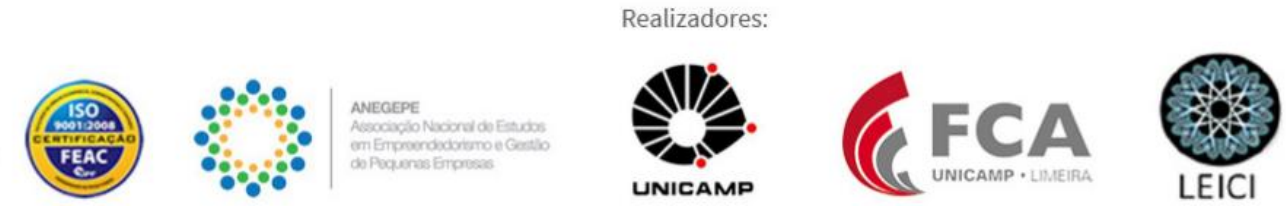
Despite of that, single case studies can also contribute to theory building and establishing the boundaries of generalization (Stake, 1998), or can be used to test theories and concepts through a deeper and longitudinal view of processes and practices related to born global firms (Welch et al 2016).

Related to the epistemological choices of the studies, all of the cases analyzed approached their research with a positivist view. Therefore, no inductive case study was found, and, in our sample, case studies are not being conducted in order to assist theory building, but to test assumptions and confirm or suggest causal relations. This aspect is relevant for the maturity of the field, which still demands reflections on the constructs and variables used to explain the phenomenon. However, it also opens venues of research to be carried out with other lenses, such as processual research or a more constructivist approach.

Concerning the sectoral analysis, 14 articles combined multiple sectors, as diverse as oil and gas, consumer goods, consulting, manufacture, etc. Apart from that, other 14 studies analyzed the internationalization aspects of high-tech firms, categorized in the Information Technology sector. Other relevant sector is Health Care (3), mainly in sectors such as bio-technology. From those figures, we understand that this phenomenon is mostly associated with technology-based or technologyoriented firms, as highlighted by Dib et al (2010) and Welch et al. (2016). However, it also shows the rapid internationalization is reaching other sectors and it is not entirely a technological event.

(Table 1 goes about here)

Results also show that most articles describe INVs based on developed countries (23 articles). A detailed analysis of the countries under scrutiny informs the readers that 10 articles analyzed firms in Australia, while 5 articles study firms from China, Thailand and India, and the other 20 articles focus on those located in European countries. Only one case belongs to a Latin American country. As the regional context of the firm can influence its internationalization process, it is fundamental to expand research on INVs to other regions beyond developing ones, so we can have a broader and more diverse empirical data to better understand and develop those concepts.

The need to regionalize this type of research is also noticed by Lopez, Kundu \& Ciravegna (2009), in a research conducted in Costa Rica, which concluded that the phenomenon is rather a regional phenomenon. More research on this topic placed in different regions, such as, Latin America, could help to corroborate findings of this sort and further develop the concept according to regional contexts. Table 1 summarizes the findings.

\subsection{Case-by-case analysis}

After the general overview, a thorough case-by-case analysis was conducted, focusing on the following categories: definition, attributes and indicators such as date of foundation, internationalization strategy (entry mode and posterior operations), international presence, country of origin, and relevance of international activities in terms of total sales (Welch et al., 2016; Dib et al., 2010).

A more qualitative analysis of the concept definition, based on firms' intrinsic characteristics allowed us to find sufficient evidence of what was also deeply analyzed by Welch and colleagues (2016), when they discuss concept stretching: several previously accepted attributes and indicators are
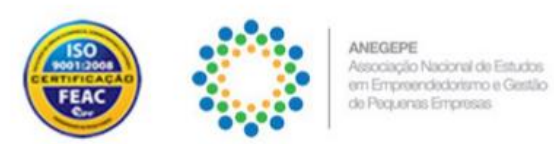

Realizadores:
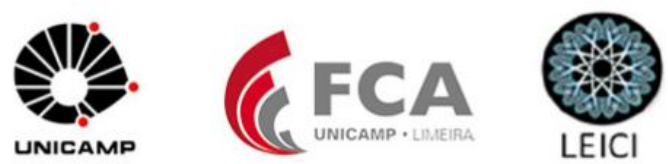
not being considered by the authors, with no theoretical assumptions that support those changes. A relevant case is the percentage of exports in terms of total sales, which was disregarded or broadly defined in more than $60 \%$ of the total cases. Table 2 supports our considerations.

A comparison of all cases suggests that the dissimilarities are even deeper. Features of the firms studied regarding date of inception, internationalization process, and geographic scope are rather distinct. Therefore, the criteria used for case selection is quite divergent among studies, reflecting a possible ad hoc posture of researchers in stretching the theory to convey their own research interests fitting the case into the theory, with insufficient attention to rigor.

Despite being considered a recent phenomenon, since the first definition was proposed by Rennie in 1993 and connected with high-tech new ventures which were embedded in global markets highly connected by internet advancements, the phenomena was also applied for analyzing similar cases in previous periods. Twenty cases studied international businesses which were founded before the 1990s and witnessed a fast internationalization process in their time. In order to avoid trying to fit the data to the theory, from our point of view those cases should be studied as idiosyncrasies of a period when classic theories of IB still applied.

(Table 2 goes about here)

Concerning the internationalization process, the mode of entry chosen by 66 INVs was exports; other 24 opted for Foreign Direct Investment (FDI) and the remaining explored their own networks to establish other contractual partnerships, such as licensing and outsourcing. An interesting fact is that 32 cases were analyzed as born-global firms, but the entry mode - one of the most important features - was not explicitly discussed, once more supporting the apparent appeal to convenience.

Several firms explored the use of personal and professional networks to explore international markets through exports and FDI - which was increased with the possibility of internet-based sales. Therefore, strategic partnerships are an important entry mode of INVs, already supporting the assumptions of Dib et al. (2010) that those firms rely on networks and use of partnerships, supported by technology and highly innovative and specialized products to guarantee a sustainable growth.

The international movement or geographic scope of the companies was not clearly presented as it should, considering it another feature that differentiate the types of INVs. However, interesting insights appear from crossing the data on the country of origin and the destination in the international market. We notice an intense North-North movement, as most INVs in the cases are European and focus its international activities in other European countries. It is interesting to highlight also a significant amount of companies from emergent and developed economies targeting the USA, for reasons such as legitimacy gain, investment seeking and/or search for a technological developed environment.

\subsection{Theoretical Implications}

Our findings suggest a confusing propagation of concepts in case studies conducted so far. What we recognize is that most studies do not explore the firm's internationalization process, and here is important to follow the recommendations of Coviello (2015, p.21): "we must distinguish between (1) firms that are truly "born" with the intent to serve multiple foreign markets quickly, and (2) firms

that simply happen to export early." Since our comprehension of the literature differentiate these type of firms, clarification of the historical evolution of the firm needs to be provided.

In the studies on INVs, this is a matter of singular importance, since without a clear definition of the internationalization process it is not possible to establish the beginning and the end of this process or even to categorize it in the several venture types. The lack of clarity also influences the quality of comparative analysis, since the juxtaposition of firm's cases without the proper consideration of its internationalization process can compromise it due missing details that can lead to completely different (or non-comparable) types of ventures or contexts of analysis.

Besides the trajectory, the information on the first targeted country for foreign investment is important to approximate or dissociate companies from classical internationalization theories, such as Uppsala (Johanson \& Vahlne, 1990). This model is defined by the authors as a gradual international involvement, dependent on the "interplay between the development of knowledge about foreign markets and operations on one hand and an increasing commitment of resources to foreign markets on the other" (Johanson \& Vahlne, 1990, p.11).

However, the INV's growing literature, which is mostly based on phenomenological analyses, contradicts the traditional stream of incremental internationalization and shows a tendency of firms entering in cultural-distant new markets. Since the country of origin can greatly influence the internationalization strategy and pace, knowing this information is crucial for differentiating INVs from traditional IB theoretical approaches when conducting a research.

By providing information about the time it takes for a firm to become international it will also assist the field to better understand the patterns related to the internationalization process and can further demonstrate how the seminal description of each type of INV is holding up in new contexts and how can these concepts evolve.

Basically, the literature on INVs understands that a firm which has passed through a rapid internationalization process fits its main definition (e.g. Rennie, 1993; Oviatt and MacDougall, 1994; Knight \& Cavusgil 1996; Knight et al. 2004). However, the term "rapid" gave rise to the emergence of several criteria upon which authors have defined the different types of INV - or even the same type. All the concepts presented in this review, as we have stated before, have been built inconsistently because many measures were created to define the same phenomenon, and, among all, the pace of internationalization is the most imprecisely defined.

This imprecision can be clearly noticed in our review. Authors suggest that most INVs internationalize within 3 years after inception, however many dissonant information were found and the pace of internationalization varied from 0 to 10 years after inception among the different venture types. Moreover, there are authors that fail to disclose the time of internationalization after inception or do so vaguely. This information is necessary to empirically understand what a rapid internationalization process is truly. Furthermore, the clarification and the careful analysis of this characteristic is fundamental to set clear boundaries to classify an INV accordingly.

Disclosing the entry mode of the INV, another relevant characteristic, also can assist researchers to better fit it into the several approaches of rapid internationalization. The entry mode of a company in the international market is associated to its commitment to foreign market (Johanson \& Vahlne, 1977, 1990), with its location choice and with the speed of the whole internationalization

Organizadores:

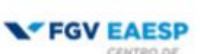

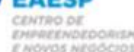
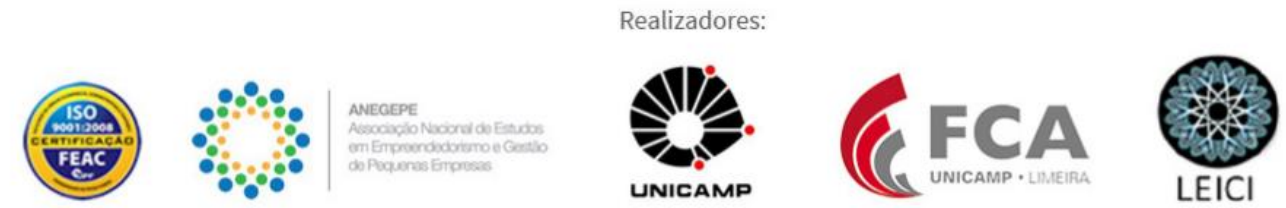
process (Dunning, 1988). Oviatt and McDougall (1994) stated that INVs do not necessarily own foreign assets, but they internationalize through different modes and high resource commitment is not required or either common. From this broad definition, as aforementioned, several other types of INVs emerged and fitting firms in the correspondent type, depending on the entry mode, avoids misinterpretations.

As our review suggests most companies choose less commitment strategies such as exports, however there is an increasing number of INV's which internationalize through FDI, for example. Another point is the lack of consistency among the reported cases in informing the company's entry mode: from 35 articles, 9 failed in giving this information. Disclosing all the features previously mentioned will assist the field to better understand this phenomenon, increase knowledge about its characteristics, assess how those companies' strategies are changing throughout time and understand the inter-relation between this entry mode and commitment to foreign market, location choice, and speed of internationalization.

As aforementioned, the theme discussed presents several similarities and unclear boundaries, which makes hard establishing the features that differentiate them. This difficulty is reflected in the literature, where conceptual stretching is clearly generating a disconnected application of all the types of INVs identified in the literature. This brief analysis goes in hand with our goal, which was not to propose a unique solution for establishing a clear construct definition, but to open it up to new appraisals that favor its consolidation. We open the venues for research efforts that, from now, must avoid $a d$ hoc construct adaptations, respecting and building on the previous research conducted so far.

\section{Moving forward: a future research agenda}

Stimulating the discussion of conceptual boundaries contributes to a better understanding of a phenomenon and supports theory building - in our analysis, the theory of international entrepreneurship gives base to the phenomenon of INVs. From the reading and interpretation of the cases and the theoretical framework used by the authors subject to this review, although often inconsistent, it was possible to identify patterns that raised theoretical gaps which still need to be discussed to the phenomenon be consolidated as a theory. Evidences such as those presented in the 167 cases emphasize the existence of companies that break with the logic of traditional models and open questions as to how these could evolve and provide a basis for a new step in International Business theory.

To explore possible ways to build and strengthen the theory of INVs, propositions were developed to be explored in future studies to confirm or not the assumptions that sustain this new internationalization rhythm based on the association of those patterns and crucial issues to the INVs, such as institutional aspects, entrepreneurial idiosyncrasies and their country of origin. By doing so we contribute to a nascent theory by consolidating the conversation on conceptual aspects and moving it to an upper level where assumptions need to be clearly stated so the theory can advance. Below we discuss each of them.

Institutional aspects and internationalization pace

Organizadores:

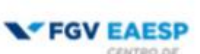

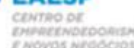
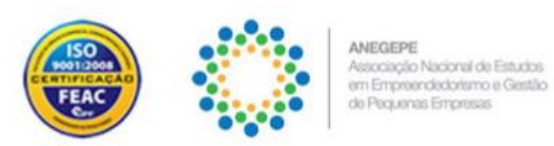
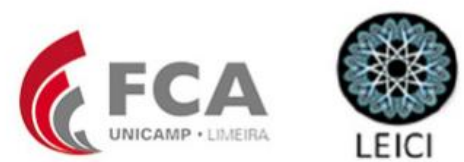
To better comprehend the internationalization process of INVs, it is necessary to take into consideration the complex connections between geographical, social and institutional aspects regarding the country of origin and destiny. Our findings suggest that depending on the country of origin, the firms presented a different internationalization pace. For example, Trudgen and Freeman (2014) found that depending on the psychic distance (Johanson \& Vahlne, 1990) between domestic and foreign markets, the speed of INVs' development phases vary. Hagen and Zucchela (2014) found that the entry in more complex markets also differentiate the growth patterns of INVs.

Even with a faster internationalization process and a highly connected environment, these firms face great challenges related to cultural, political, and/or language barriers, supporting traditional IB theories. However, as Freeman, Hutchings, and Chetty (2012) suggest, INVs tend to be proactive when entering culturally non-proximate markets, rapidly overcoming probable difficulties by migrating to other proximate countries or finding alternatives to support the firm's survival in a hostile environment. In addition, our data reveals an intense movement from countries culturally-distant (South-North movements). Thus, despite the challenges, psychic distance does not hinder INVs expansion to far distant markets. Therefore, we propose:

Proposition 1: Cultural, political, and language differences between home and foreign markets interfere on the internationalization pace of international new ventures, but do not hinder their expansion.

\section{Country of origin and the purpose of internationalization}

Whether a firm follows the gradual path or assumes a risk-taking attitude neglecting issues related to psychic distance interferes in how to categorize it in the different types of internationalized businesses. Combined with the firm's main purpose when created, this information reveals a great deal about the framed concept, allowing to identify, define or even test patterns related to this set of unique behavior and attributes.

In this context, international moves to culturally-distant countries are found to be related to other intentions than the obvious expansion of markets served by the firm. INVs, especially those from emerging markets, tend to pursue international activities in developed countries aiming to legitimate their products or brands (Mort, Weerawardena, \& Liesch, 2012; Sepulveda \& Gabrielsson, 2013; Turcan, 2011). One possible explanation for this behavior identified in our review is the association with poor governance in their home market and also the possibility to raise funds (Bangara, Freeman, \& Schroder, 2012).

On the other hand, a noteworthy North-North movement is also noticed. These firms, as aforementioned, are mostly Europeans and migrate to other developed countries. Mostly, those firms seek to access similar markets to expand its activities due to size limitation and stagnation of domestic markets (Chandra, Styles, \& Wilkinson, 2012; Freeman, Hutchings, \& Chetty, 2012; Heweverdine \& Welch, 2013; Turcan 2011; Hewerdine, Rumyantseva, \& Welch, 2014; Vasilchenko e Morrish, 2011; Taylor \& Jack, 2013), which leads to an intense domestic competition (Hermel \& Khayat, 2011). Hence, we propose:

Proposition 2a: International new ventures from emerging markets mostly seek legitimacy when undertaking international activities.
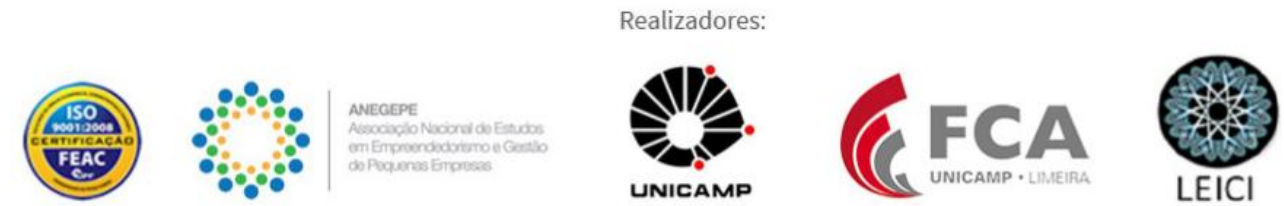
Proposition 2b: International new ventures from developed markets mostly seek market expansion when undertaking international activities.

\section{Internationalization pace and entrepreneurial idiosyncrasies}

The features of the entrepreneur's mindset are significantly related with the INV internationalization pace. An INV has a restrict social capital and therefore seeks for power and legitimacy in foreign markets (Lindstrand et. al, 2011). The INV' manager accepts the risk of operating in international markets, using his abilities to manage the planned and unplanned steps of this process (Bangara, 2012).

As suggested by some of the cases analyzed, the entrepreneur's social network also has an essential role on the firm internationalization pace as it can potentially lead to collaborative cooperation and might facilitate the exploitation of internationalization opportunities culminated by successful entry into foreign markets (Vasilchenko \& Morrish, 2011). The network acquired prior to the founding of the INV proved to have great implications for growth and internationalization in the young firms (Pettersen \& Tobiassen, 2012). Freeman, Hutchings \& Chetty (2012) also noticed that they leverage technological knowledge and networks to move faster towards nearby non-proximate $\mathrm{m}$

Lastly, another important feature related to the entrepreneur is his previous international experience. Overseas experience is framed in several cases as a driver and facilitator of rapid internationalization (Zou \& Ghauri, 2010; Gabrielsson \& Gabrielsson, 2011; Yan \& Panteli, 2011; Mort, Weerawardena, \& Liesch, 2012; Kungwansupaphan \& Diengthai, 2014). Previous international knowledge, as well as the entrepreneur's personal network, ease the challenges when facing culturallydistant or complex markets, speeding the adaptation process. As mentioned by Glavas and Mathews (2014), both international experience and international network are more efficient than the internet in supporting the internationalization process. Therefore, we suggest that:

Proposition 3a: The internationalization pace is influenced by the entrepreneur international network developed prior to the international new venture founding.

Proposition 3b: The internationalization pace is influenced by the entrepreneur international experience developed prior to the international new venture founding.

\section{Conclusions}

Through a systematized analysis of 35 articles which summed a total of 167 case studies regarding INVs, this article integrated the knowledge developed through empirical researches and opened venues to better comprehend the rapid internationalization process of the firms. The initial results indicate some overall aspects regarding INV's, from which we drawn our propositions regarding main patterns of an international new venture. These companies' internationalization pace is interfered by cultural, political and language differences, however those conditions don't limit their expansion. Additionally, the INV's internationalization purposes are impacted by its country of origin. Similarly, the entrepreneur characteristics are determinant to the firms' internationalization process and international market commitment.
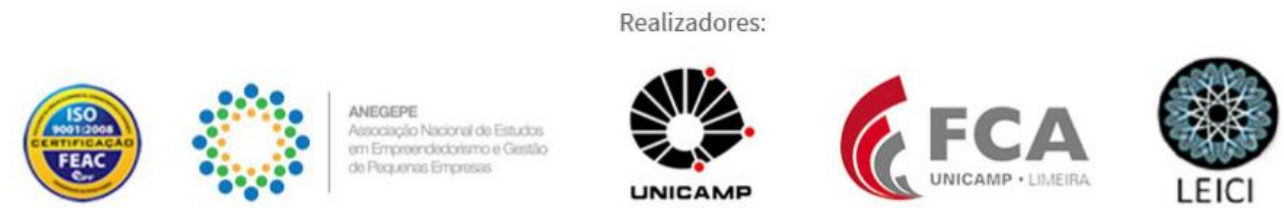
Besides the above-mentioned propositions, this review also grasped conceptual issues related to INV's, as it is still broad and inconsistent throughout the literature analyzed. These issues became clear as we noticed the lack of based and consistent description of the INV's throughout the case studies, what can be a problem as researchers need to trace back the historical foundation of the company to verify if it fits the theory - avoiding conceptual stretching or conventionalized case selection (Ragin, 1992).

When important information about the firm internationalization process is regardless omitted or not truly investigated, we miss the opportunity to create a clear image of what the work is about: which type of INV is under investigation. Still, it opens the debate for a more critical analysis of the theory developed so far, contributing to a more coherent growing of this field of research.

In this sense, it is important to highlight the imprudent posture in using the different types of INVs interchangeably. For a more solid development of the field, the discussion of "How fast is rapid?" should be clarified and future studies should concentrate in understanding the internationalization process of those companies deeply and under different conditions and contexts to validate the concepts already consolidated in the literature.

By pointing to INV's characteristics which seems to be strongly related to its country of origin, its cultural, political and language aspects, and as well to the entrepreneur's idiosyncrasies, we notice how particular can be the antecedents of this phenomenon and therefore we suggest to future researchers to considerer a more rigorous process before defining companies as INV's. Moreover, a thoroughly and minimum standardized description of the firms under study will only help the field to better understand and develop the phenomena.

Important for corroborating the phenomenon is also to develop future studies focused on better understanding the process after the rapid internationalization. Along with our propositions, which could be deeper investigated in a more rigorous process, we also consider that, as most of those companies have to deal with knowledge (Zarei et al, 2011) and resource scarcity, it is important to analyze how the internationalization process is sustained in a long-term perspective.

Although some authors have brought to light studies in emerging countries ( $\mathrm{Su}, 2013$; Zarei et al, 2011; Zou \& Ghauri, 2011), those tend to be concentrated in countries such as China. Therefore, is not only recommended that more studies investigate the rapid internationalization of firms from developing countries, but is also important that those consider different contexts, such as emerging countries from different regions, to bring a more comprehensive perspective of the phenomena. Although an incipient movement has started, regional diversification of the studies could open the discussion on the generalization of the concept.

Despite important aspects of the phenomena were explored in the case studies we analyzed in this review, future research could deepen the understanding on barriers and drivers of the rapid internationalization process. Such findings may lead to a comprehensive understanding of cultural, political and economic conditions that can spur such ventures. Researchers could expand what was initially attempted in this manuscript and contribute even more to the consolidation of such recent research field.
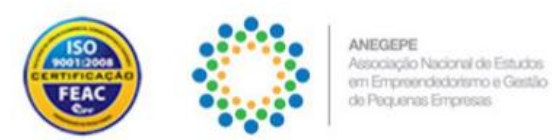

Realizadores:
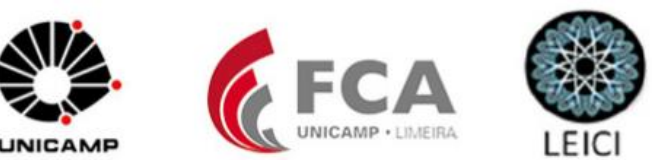


\section{References}

Badera, T., \& Mazzarola, T. (2009). Defining the Born Global Firms: A Review of the Literature, Australian and New Zealand Academy of Management. Managing in the Pacific Century, 24th Annual ANZAM Conference, December, Melbourne, Australia.

Bangara, A., Freeman, S., \& Schroder, W. (2012). Legitimacy and accelerated internationalisation: An Indian perspective. Journal of World Business, 47(4), 623-634.

Chandra, Y., Styles, C., \& Wilkinson, I. F. (2012). An opportunity-based view of rapid internationalization. Journal of International Marketing, 20(1), 74-102.

Chetty, S., \& Campbell-Hunt, C. (2004). A strategic approach to internationalization: a traditional versus a "born-global" approach. Journal of International Marketing, 12(1), 57-81.

Coelho, B. V., de Mello, R. C., \& da Rocha, A. (2014). Leblon Cachaça: A born global in a traditional industry. Journal of Business Research, 67(4), 567-575.

Coviello, N. (2015). Re-thinking research on born globals. Journal of International Business Studies, 46(1), 17-26.

Dib, L.A., Rocha, A., Silva, J.F. (2010). The internationalization process of Brazilian software firms and the born global phenomenon: examining firm, network, and entrepreneur variables. Journal of International Entrepreneurship, v.8, 233-253.

Dimitratos, P., Johnson, J. E., Plakoyiannaki, E., \& Young, S. (2016). SME internationalization: How does the opportunity-based international entrepreneurial culture matter? International Business Review, 25(6), 1211-1222.

Dimitratos, P., Amorós, J. E., Etchebarne, M. S., \& Felzensztein, C. (2014). Micro-multinational or not? International entrepreneurship, networking and learning effects. Journal of Business Research, 67(5), 908-915.

Dimitratos, P., Johnson, J. E., Slow, J., \& Young, S. (2003). Micro-multinationals: New types of firms for the global competitive landscape. European Management Journal, 21(2), 164-174.

Edmondson, A.C., \& McManus, S.E. (2007). Methodological fit in management field research. Academy of Management Review, v.32, n.4, 1155-1179.

Eisenhardt, K.M. (1989). Building theories from case study research. Academy of Management Review, v.14, n.4, 532-550.

Eisenhardt, K. M., \& Grebner, M. E. (2007). THEORY BUILDING FROM CASES: OPPORTUNITIES AND CHALLENGES. Academy of Management Journal, 50(1), 25-32. https://doi.org/10.5465/AMJ.2007.24160888

Fletcher, M., \& Harris, S. (2012). Knowledge acquisition for the internationalization of the smaller firm: Content and sources. International Business Review, 21(4), 631-647.

Freeman, S., Hutchings, K., \& Chetty, S. (2012). Born-globals and culturally proximate markets. Management International Review, 52(3), 425-460.

Gabrielsson, M., \& Gabrielsson, P. (2011). Internet-based sales channel strategies of born global firms. International Business Review, 20(1), 88-99.

Gabrielsson, M., Gabrielsson, P., \& Dimitratos, P. (2014). International entrepreneurial culture and growth of international new ventures. Management International Review, 54(4), 445-471.
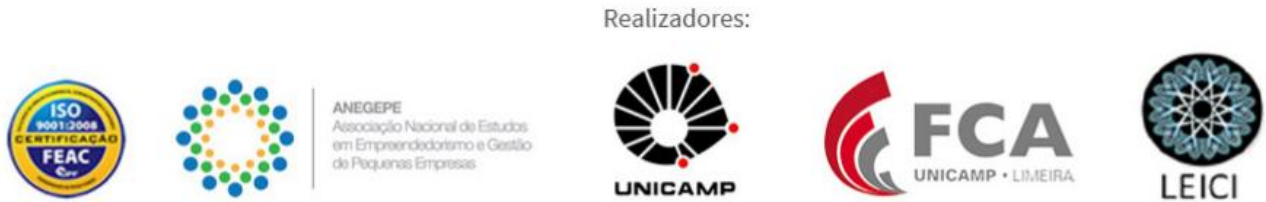
Gabrielsson, M., Sasi, V., \& Darling, J. (2004). Finance strategies of rapidly-growing Finnish SMEs: born internationals and born globals. European Business Review, 16(6), 590-604.

Glaser, B., \& Strauss, A. (1967). The discovery of grounded theory: strategies of qualitative research. London: Weidenfeld and Nicholson.

Glavas, C., \& Mathews, S. (2014). How international entrepreneurship characteristics influence Internet capabilities for the international business processes of the firm. International Business Review, 23(1), 228-245.

Hagen, B., \& Zucchella, A. (2014). Born global or born to run? The long-term growth of born global firms. Management International Review, 54(4), 497-525.

Hashai, N., \& Almor, T. (2004). Gradually internationalizing 'born global' firms: an oxymoron? International Business Review, 13(4), 465-483.

Hermel, P., \& Khayat, I. (2011). The role of resources: micro-firms internationalization in the French context. Journal of Small Business and Enterprise Development, 18(2), 298-310.

Hewerdine, L., \& Welch, C. (2013). Are international new ventures really new? A process study of organizational emergence and internationalization. Journal of World Business, 48(4), 466-477.

Johanson, J., \& Vahlne, J. E. (1977). The internationalization process of the firm-a model of knowledge development and increasing foreign market commitments. Journal of international business studies, 8(1), 23-32.

Knight, G., Cavusgil, S. (1996) The born global firm: a challenge to traditional internationalization theory. In: Cavusgil S, Madsen K (eds) Export internationalizing research-enrichment and challenges. Advances in International Marketing, 8:11-26.

Knight, G., Koed Madsen, T., \& Servais, P. (2004). An inquiry into born-global firms in Europe and the USA. International Marketing Review, 21(6), 645-665.

Kontinen, T., \& Ojala, A. (2012). Internationalization pathways among family-owned SMEs. International Marketing Review, 29(5), 496-518.

Kungwansupaphan, C., \& Siengthai, S. (2014). Exploring entrepreneurs' human capital components and effects on learning orientation in early internationalizing firms. International Entrepreneurship and Management Journal, 10(3), 561-587.

Langseth, H., O'Dwyer, M., \& Arpa, C. (2016). Forces influencing the speed of internationalization: An exploratory Norwegian and Irish study. Journal of Small Business and Enterprise Development, 23(1), 122-148.

Lindstrand, A., Melén, S., \& Nordman, E. R. (2011). Turning social capital into business: A study of the internationalization of biotech SMEs. International Business Review, 20(2), 194-212.

Lopez, L. E., Kundu, S. K., \& Ciravegna, L. (2009). Born global or born regional? Evidence from an exploratory study in the Costa Rican software industry. Journal of International Business Studies, 40(7), 1228-1238.

Mainela, T., Pernu, E., \& Puhakka, V. (2011). The development of a high-tech international new venture as a process of acting: A study of the lifespan of a venture in software business. Journal of Small Business and Enterprise Development, 18(3), 430-456.

McDougall, P. P. (1989). International versus domestic entrepreneurship: new venture strategic behavior and industry structure. Journal of Business Venturing, 4(6), 387-400.
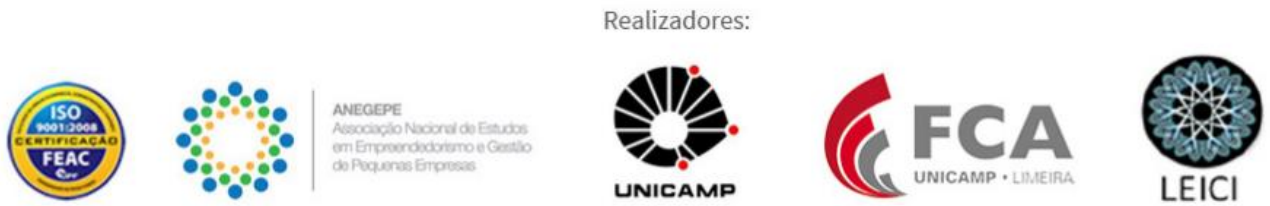
McDougall, P. P., Shane, S., \& Oviatt, B. M. (1994). Explaining the formation of international new ventures: The limits of theories from international business research. Journal of business venturing, 9(6), 469-487.

Moen, Ø. (2002). The born globals: a new generation of small European exporters. International Marketing Review, 19(2), 156-175.

Mort, G. S., \& Weerawardena, J. (2006). Networking capability and international entrepreneurship: How networks function in Australian born global firms. International Marketing Review, 23(5), 549-572.

Mort, G. S., Weerawardena, J., \& Liesch, P. (2012). Advancing entrepreneurial marketing: Evidence from born global firms. European Journal of Marketing, 46(3/4), 542-561.

Nummela, N., Saarenketo, S., \& Loane, S. (2016). The dynamics of failure in international new ventures: A case study of Finnish and Irish software companies. International Small Business Journal, 34(1), 51-69.

Oviatt, B. M., \& McDougall, P. P. (1994). Toward a theory of international new ventures. Journal of international business studies, 25(1), 45-64.

Oviatt, B. M., McDougall, P. P., \& Loper, M. (1995). Global start-ups: entrepreneurs on a worldwide stage [and executive commentary]. The Academy of Management Executive (1993-2005), 3044.

Pettersen, I. B., \& Tobiassen, A. E. (2012). Are born globals really born globals? The case of academic spin-offs with long development periods. Journal of International Entrepreneurship, 10(2), 117-141.

Prashantham, S., \& Dhanaraj, C. (2015). MNE ties and new venture internationalization: Exploratory insights from India. Asia Pacific Journal of Management, 32(4), 901-924.

Rasmussan, E. S., Koed Madsen, T., \& Evangelista, F. (2001). The founding of the born global company in Denmark and Australia: Sensemaking and networking. Asia Pacific Journal of Marketing and Logistics, 13(3), 75-107.

Rasmussen, E., Madsen, T. (2002). The born global concept. Proceedings of the 28th EIBA Annual Conference. Athens, Greece: European International Business Academy

Rennie, M. W. (1993). Born global. The McKinsey Quarterly, (4), 45-53.

Rundh, B. (2015). International market development: the small and medium sized firm's opportunity or dilemma. Management Decision, 53(6), 1329-1354.

Sepulveda, F., \& Gabrielsson, M. (2013). Network development and firm growth: A resource-based study of B2B Born Globals. Industrial Marketing Management, 42(5), 792-804.

Stake, R.E. (1998). Qualitative case studies. In: Handbook of Qualitative Research. 443-466.

$\mathrm{Su}, \mathrm{N}$. (2013). Internationalization strategies of Chinese IT service suppliers. MIS Quarterly, 37(1), 175-200.

Taylor, M., \& Jack, R. (2013). Understanding the pace, scale and pattern of firm internationalization: An extension of the 'born global'concept. International Small Business Journal, 31(6), 701721.

Thistoll, T., \& Pauleen, D. (2010). Commercializing innovation internationally: A case study of social network and relationship management. Journal of International Entrepreneurship, 8(1), 36-54.
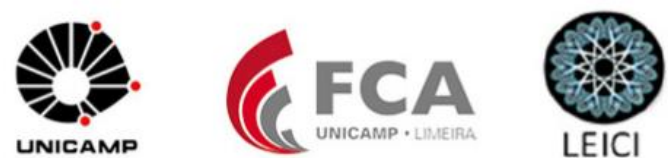
Trudgen, R., \& Freeman, S. (2014). Measuring the performance of born-global firms throughout their development process: The roles of initial market selection and internationalization speed. Management International Review, 54(4), 551-579.

Turcan, R. V. (2011). Toward a theory of international new venture survivability. Journal of international entrepreneurship, 9(3), 213-232.

United Nations. (2014). World Economic Situation and Prospects - Country Classification. Available from

http://www.un.org/en/development/desa/policy/wesp/wesp_current/2014wesp_country_classific ation.pdf

Vasilchenko, E., \& Morrish, S. (2011). The role of entrepreneurial networks in the exploration and exploitation of internationalization opportunities by information and communication technology firms. Journal of International Marketing, 19(4), 88-105.

Voudouris, I., Dimitratos, P., \& Salavou, H. (2011). Entrepreneurial learning in the international new high-technology venture. International Small Business Journal, 29(3), 238-258.

Wach, K. \& Wehrmann, C. (2014). Entrepreneurship in International Business: International Entrepreneurship as the Intersection of Two Fields (chapter 1). In: Gubik, A.S. \& Wach, K. (eds), International Entrepreneurship and Corporate Growth in Visegrad Countries. Mickolc: University of Miskolc, pp. 9-22.

Weerawardena, J., Mort, G. S., Salunke, S., Knight, G., \& Liesch, P. W. (2015). The role of the market sub-system and the socio-technical sub-system in innovation and firm performance: a dynamic capabilities approach. Journal of the Academy of Marketing Science, 43(2), 221-239.

Welch, C., Rumyantseva, M., \& Hewerdine, L. J. (2016). Using case research to reconstruct concepts: A methodology and illustration. Organizational Research Methods, 19(1), 111-130.

Whetten, D. A. (1989). What Constitutes a Theoretical Contribution? Academy of Management Review, 14(4), 490-495. https://doi.org/10.5465/AMR.1989.4308371c

Yan, L., \& Panteli, N. (2011). Order and disorder in a Born Global organization. New Technology, Work and Employment, 26(2), 127-145.

Zander, I., McDougall-Covin, P., \& Rose, E. L. (2015). Born globals and international business: Evolution of a field of research. Journal of International Business Studies, 46(1), 27-35.

Zou, H., \& Ghauri, P. N. (2010). Internationalizing by learning: the case of Chinese high-tech new ventures. International Marketing Review, 27(2), 223-244.

Zucchella, A. (2002). Born global versus gradually internationalizing firms: an analysis based on the Italian case. Proceedings of the 28th EIBA Annual Conference. Athens, Greece: European International Business Academy.
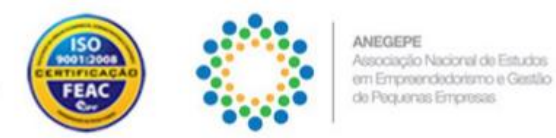

Realizadores:
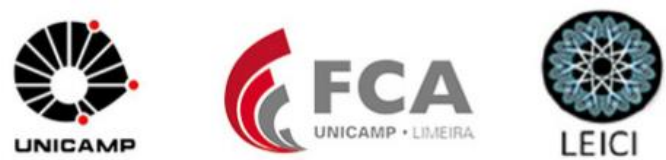


\section{International Entrepreneurship}

"[...] development of international new ventures or start-ups that, from their inception, engage in international business, thus viewing their operating domain as international from the initial stages of the firm's operation" (McDougall, 1989).

\section{International New Venture}

A business organization that, from inception, seeks to derive significant competitive advantage from the use of resources and sale of outputs in multiple countries (Oviatt \& McDougal, 1994)

\begin{tabular}{|c|c|c|}
\hline $\begin{array}{c}\text { Micro Multinationals } \\
\text { mMNEs are smaller firms that employ } \\
\text { advanced (non-exporting) foreign } \\
\text { market servicing modes to tap into } \\
\text { opportunities abroad. (Dimitratos, } \\
\text { Johnson, Slow\& Young; 2003) }\end{array}$ & $\begin{array}{c}\text { Global Start-ups } \\
\text { is the most radical manifestation of } \\
\text { the international new venture that } \\
\text { it is discovered (McDougall, Shane and } \\
\text { Oviatt, 1994). }\end{array}$ & $\begin{array}{c}\text { Born Global Firms } \\
\text { Business organizations that, from or near } \\
\text { their founding, seek superior international } \\
\text { business performance from the application } \\
\text { of knowledge-based resources to the sale of } \\
\text { outputs in multiple countries } \\
\text { (Knight \& Cavusgil, 2004). }\end{array}$ \\
\hline
\end{tabular}

Figure 1.

International new ventures and the field of research

Source: Developed by the authors

\section{Articles per Journals}

New Technology Work and Employment

Management International Review

Management Decision

Journal of the Academy of Marketing Science

Journal of International Marketing

Journal of Business Research

International Small Business Journal

International Entrepreneurship And.

Industrial Marketing Management

Asia Pacific Journal of Management.

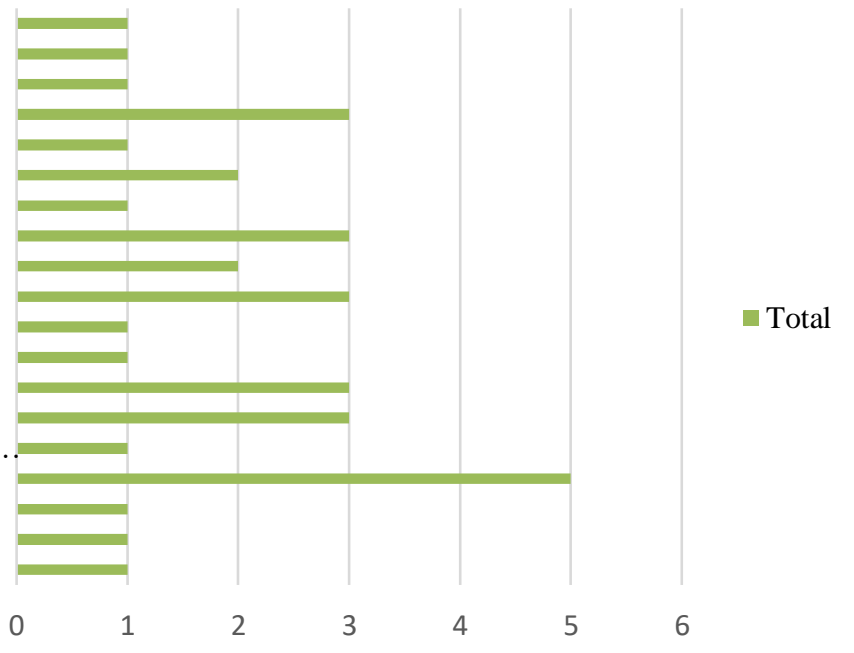

\section{Graphic 1.}

Articles per journal

Source: Developed by the authors 


\section{Table 1.}

Concepts and focus

\begin{tabular}{|c|c|c|c|c|}
\hline Research Focus & Concept & Authors & $\begin{array}{l}\text { Case Home } \\
\text { Country }\end{array}$ & Case Sector \\
\hline \multirow{3}{*}{$\begin{array}{c}\text { DRIVERS OF } \\
\text { RAPID } \\
\text { INTERNATIONALIZATION }\end{array}$} & Born Global & $\begin{array}{c}\text { Weerawardena, Mort, } \\
\text { Salunke, Knight \& Liesch (2015) }\end{array}$ & Australia, US & Multiple Sectors \\
\hline & $\begin{array}{l}\text { International } \\
\text { Entrepreneurship }\end{array}$ & $\begin{array}{c}\text { Langseth, O'Dwyer \& Arpa } \\
(2016)\end{array}$ & Norway, Ireland & Multiple Sectors \\
\hline & $\begin{array}{l}\text { International New } \\
\text { Ventures }\end{array}$ & Hermel \& Khayat (2011) & France & Health Care \\
\hline \multirow[t]{7}{*}{$\begin{array}{l}\text { ENTREPRENEURIA } \\
\text { L ASPECTS }\end{array}$} & \multirow[t]{3}{*}{ Born Global } & $\begin{array}{l}\text { Bangara, Freeman \& } \\
\text { Schroder (2012) }\end{array}$ & India & Multiple Sectors \\
\hline & & $\begin{array}{l}\text { Gabrielsson, Gabrielsson \& } \\
\text { Dimitratos (2014) }\end{array}$ & Finland & Multiple Sectors \\
\hline & & $\begin{array}{l}\text { Kungwansupaphan \& } \\
\text { Siengthai (2014) }\end{array}$ & Thailand & Consumer Staples \\
\hline & \multirow[t]{2}{*}{$\begin{array}{l}\text { International } \\
\text { Entrepreneurship }\end{array}$} & Glavas \& Mathews (2014) & \multicolumn{2}{|c|}{ Discretionary } \\
\hline & & $\begin{array}{c}\text { Dimitratos, Johnson, } \\
\text { Plakoyiannaki \& Young (2016) }\end{array}$ & USA, UK, Greece & Multiple Sectors \\
\hline & \multirow[t]{2}{*}{$\begin{array}{l}\text { International New } \\
\text { Ventures }\end{array}$} & $\begin{array}{l}\text { Voudouris, Dimitratos \& } \\
\text { Salavou (2011) }\end{array}$ & Greece & $\begin{array}{l}\text { Information } \\
\operatorname{logy}\end{array}$ \\
\hline & & $\begin{array}{l}\text { Nummela, Saarenketo \& } \\
\text { Loane (2016) }\end{array}$ & \multicolumn{2}{|c|}{ Technology } \\
\hline GROWTH AND & Born Global & Yan \& Panteli (2011) & Holland/Italy & Industrials \\
\hline
\end{tabular}

Organizadores:

-figv eaesp charmo of noment 


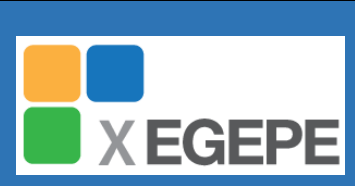

\begin{tabular}{|c|c|c|c|c|}
\hline \multirow[t]{3}{*}{ PERFORMANCE } & & Hagen \& Zucchella (2014) & Austria & Multiple Sectors \\
\hline & & Trudgen \& Freeman (2014) & Australia & Multiple Sectors \\
\hline & $\begin{array}{l}\text { International New } \\
\text { Ventures }\end{array}$ & Turcan (2011) & Scotland & $\begin{array}{l}\text { Information } \\
\log \mathrm{y}\end{array}$ \\
\hline \multirow[t]{8}{*}{$\begin{array}{l}\text { IMPORTANCE OF } \\
\text { NETWORK RELATIONS }\end{array}$} & \multirow[t]{3}{*}{ Born Global } & $\begin{array}{l}\text { Vasilchenko \& Morrish } \\
\text { (2011) }\end{array}$ & New Zeland & $\begin{array}{l}\text { Information } \\
\operatorname{logy}\end{array}$ \\
\hline & & $\begin{array}{l}\text { Pettersen \& Tobiassen } \\
\quad \text { (2012) }\end{array}$ & Norway & $\begin{array}{l}\text { Information } \\
\operatorname{logy}\end{array}$ \\
\hline & & $\begin{array}{l}\text { Sepulveda \& Gabrielsson } \\
\text { (2013) }\end{array}$ & Finland & Multiple Sectors \\
\hline & \multirow{2}{*}{$\begin{array}{l}\text { International } \\
\text { Entrepreneurship }\end{array}$} & Fletcher \& Harris (2012) & Scotland & Multiple Sectors \\
\hline & & $\begin{array}{l}\text { Prashantham \& Dhanaraj } \\
\text { (2015) }\end{array}$ & India & $\begin{array}{l}\text { Information } \\
\operatorname{logy}\end{array}$ \\
\hline & \multirow[t]{3}{*}{$\begin{array}{l}\text { International New } \\
\text { Ventures }\end{array}$} & Thistoll \& Pauleen (2010) & Australia & $\begin{array}{l}\text { Information } \\
\operatorname{logy}\end{array}$ \\
\hline & & $\begin{array}{l}\text { Lindstrand, Melen \& } \\
\text { Nordman (2011) }\end{array}$ & Sweden & Health Care \\
\hline & & $\begin{array}{l}\text { Mainela, Pernu \& Puhakka } \\
\text { (2013) }\end{array}$ & Finland & $\begin{array}{l}\text { Information } \\
\log y\end{array}$ \\
\hline \multirow[t]{4}{*}{$\begin{array}{l}\text { INTERNATIONALI } \\
\text { ZATION STRATEGY }\end{array}$} & \multirow[t]{4}{*}{ Born Global } & $\begin{array}{l}\text { Freeman, Hutchings } \\
\& \text { Chetty (2012) }\end{array}$ & Australia & $\begin{array}{l}\text { Information } \\
\operatorname{logy}\end{array}$ \\
\hline & & $\begin{array}{l}\text { Chandra, Styles \& } \\
\text { Wilkinson (2012) }\end{array}$ & Australia & Multiple Sectors \\
\hline & & $\mathrm{Su}(2013)$ & China & $\begin{array}{l}\text { Information } \\
\log y\end{array}$ \\
\hline & & Taylor \& Jack (2013) & Australia & Multiple Sectors \\
\hline
\end{tabular}

Organizadores:

- fov eaesp conteo or
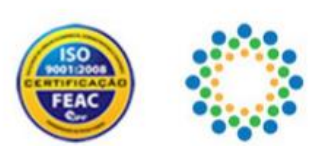

N

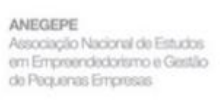

Realizadores:

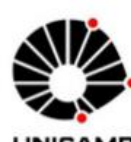

UNICAMP 


\begin{tabular}{|c|c|c|c|c|c|c|}
\hline & & $\begin{array}{l}\text { Hewerdine, Rumyantseva \& } \\
\text { Welch (2014) }\end{array}$ & & \multicolumn{3}{|c|}{ Technology } \\
\hline & & $\begin{array}{l}\text { Coelho, Mello \& Rocha } \\
\text { (2014) }\end{array}$ & USA & Brazil, & France, & Consumer Staples \\
\hline & $\begin{array}{l}\text { International } \\
\text { Entrepreneurship }\end{array}$ & Kontinen \& Ojala (2012) & & Finland & & Multiple Sectors \\
\hline & \multirow[t]{3}{*}{$\begin{array}{l}\text { International New } \\
\text { Ventures }\end{array}$} & Zou \& Ghauri (2010) & & China & Technology & $\begin{array}{l}\text { Information } \\
\operatorname{logy}\end{array}$ \\
\hline & & Hewerdine \& Welch (2013) & & Australia & & Health Care \\
\hline & & Rundh (2015) & & Sweden & & Multiple Sectors \\
\hline \multirow[t]{3}{*}{$\begin{array}{l}\text { MARKETING } \\
\text { ASPECTS }\end{array}$} & \multirow[t]{3}{*}{ Born Global } & $\begin{array}{l}\text { Altshuler \& Tarnavskaya } \\
\text { (2010) }\end{array}$ & & Denmark & & $\begin{array}{l}\text { Information } \\
\text { logy }\end{array}$ \\
\hline & & $\begin{array}{l}\text { Gabrielsson \& Gabrielsson } \\
\text { (2011) }\end{array}$ & & Finland & \multicolumn{2}{|c|}{ Technology } \\
\hline & & $\begin{array}{l}\text { Mort, Weerawardena \& } \\
\text { Liesch }(2012)\end{array}$ & & Australia & & Multiple Sectors \\
\hline
\end{tabular}

Source: Developed by the authors.

\section{Organizadores:}

- fov eaesp arous
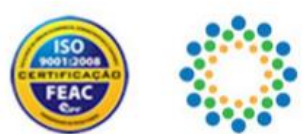
Table 2.

Aspects disregarded by the authors

\begin{tabular}{|c|c|c|c|}
\hline $\begin{array}{l}\text { Aspect not } \\
\text { considered }\end{array}$ & Author & ear & Concept Employed \\
\hline \multirow[t]{10}{*}{$\begin{array}{c}\text { Pace of } \\
\text { internationalization }\end{array}$} & Fletcher \& Harris & 012 & Born Global \\
\hline & Kungwansupaphan \& Siengthai & & Born Global \\
\hline & & 014 & \\
\hline & Pettersen \& Tobiassen & & Born Global \\
\hline & & 012 & \\
\hline & Prashantham \& Dhanaraj & 015 & $\begin{array}{l}\text { International } \\
\text { Entrepreneurship }\end{array}$ \\
\hline & $\mathrm{Su}$ & & Born Global \\
\hline & & 013 & \\
\hline & Thistoll \& Pauleen & 010 & Born Global \\
\hline & Trudgen \& Freeman & 014 & Born Global \\
\hline \multirow{9}{*}{$\begin{array}{l}\text { Entry } \\
\text { Mode }\end{array}$} & Fletcher \& Harris & & Born Global \\
\hline & 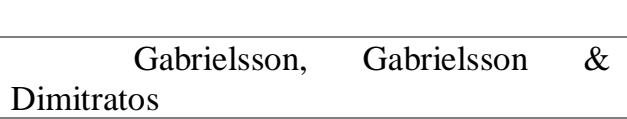 & 014 & Born Global \\
\hline & Glavas \& Mathews & 014 & Born Global \\
\hline & Hewerdine \& Welch & 013 & $\begin{array}{l}\text { International New } \\
\text { Ventures }\end{array}$ \\
\hline & Kungwansupaphan \& Siengthai & 014 & Born Global \\
\hline & Langseth, O'Dwyer \& Arpa & 016 & Born Global \\
\hline & Lindstrand, Melen \& Nordman & 011 & Born Global \\
\hline & Thistoll \& Pauleen & 010 & Born Global \\
\hline & Trudgen \& Freeman & 014 & Born Global \\
\hline \multirow[t]{5}{*}{$\begin{array}{l}\text { Internation } \\
\text { al Presence }\end{array}$} & Bangara, Freeman \& Schroder & 012 & Born Global \\
\hline & Chandra, Styles \& Wilkinson & 012 & Born Global \\
\hline & Coelho, Mello \& Rocha & 014 & Born Global \\
\hline & $\begin{array}{c}\text { Dimitratos, } \\
\text { Plakoyiannaki \& Young }\end{array}$ & 016 & Born Global \\
\hline & Fletcher \& Harris & 012 & Born Global \\
\hline
\end{tabular}




\begin{tabular}{|c|c|c|c|c|}
\hline & Gabrielsson \& Gabrielsson & & Born Global & \\
\hline & & 011 & & \\
\hline & $\begin{array}{l}\text { Gabrielsson, Gabrielsson } \quad \& \\
\text { Dimitratos }\end{array}$ & 014 & Born Global & \\
\hline & Hermel \& Khayat & & Born Global & \\
\hline & & 011 & & \\
\hline & Hewerdine \& Welch & & International & New \\
\hline & & 013 & Ventures & \\
\hline & Kungwansupaphan \& Siengthai & & Born Global & \\
\hline & & 014 & & \\
\hline & Langseth, O'Dwyer \& Arpa & & Born Global & \\
\hline & & 016 & & \\
\hline & Lindstrand, Melen \& Nordman & & Born Global & \\
\hline & & 011 & & \\
\hline & Nummela, Saarenketo \& Loane & & Born Global & \\
\hline & & 016 & & \\
\hline & Pettersen \& Tobiassen & & Born Global & \\
\hline & & 012 & & \\
\hline & Prashantham \& Dhanaraj & 015 & $\begin{array}{l}\text { International } \\
\text { Entrepreneurship }\end{array}$ & \\
\hline & Rundh & & International & New \\
\hline & & 015 & Ventures & \\
\hline & Taylor \& Jack & & Born Global & \\
\hline & & 013 & & \\
\hline & Turcan & & Born Global & \\
\hline & & 011 & & \\
\hline & Voudouris, Dimitratos \& Salavou & & Born Global & \\
\hline & & 011 & & \\
\hline & $\begin{array}{cc}\text { Weerawardena, } & \text { Mort, } \\
\text { Salunke, Knight \& Liesch } & \end{array}$ & 015 & Born Global & \\
\hline & Yan \& Panteli & & Born Global & \\
\hline & & 011 & & \\
\hline Target & Altshuler \& Tarnavskaya & & Born Global & \\
\hline Market & & 010 & & \\
\hline & $\begin{array}{cc}\text { Dimitratos, } & \text { Johnson, } \\
\text { Plakoyiannaki \& Young } & \end{array}$ & 016 & Born Global & \\
\hline & Fletcher \& Harris & & Born Global & \\
\hline & & 012 & & \\
\hline & Gabrielsson \& Gabrielsson & & Born Global & \\
\hline & & 011 & & \\
\hline & $\begin{array}{l}\text { Gabrielsson, Gabrielsson } \& \\
\text { Dimitratos }\end{array}$ & 014 & Born Global & \\
\hline & Glavas \& Mathews & & Born Global & \\
\hline & & 014 & & \\
\hline & Kungwansupaphan \& Siengthai & & Born Global & \\
\hline & & 014 & & \\
\hline & Langseth, O'Dwyer \& Arpa & & Born Global & \\
\hline & & 016 & & \\
\hline & Lindstrand, Melen \& Nordman & & Born Global & \\
\hline & & 011 & & \\
\hline & Mort, & 012 & Born Global & \\
\hline
\end{tabular}




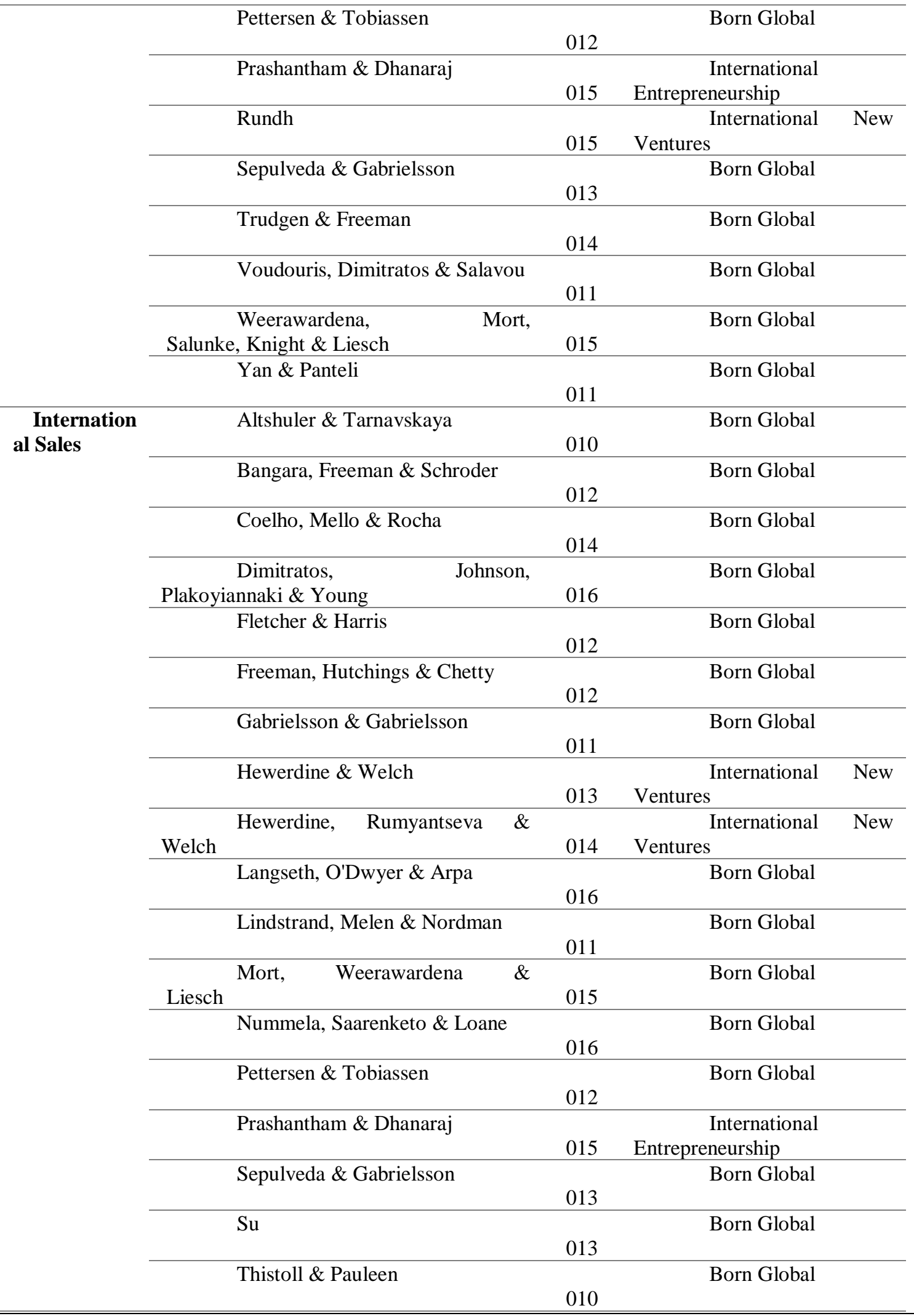




\begin{tabular}{lcl} 
Trudgen \& Freeman & 014 & Born Global \\
\hline Turcan & 011 & Born Global \\
\hline Vasilchenko \& Morrish & 011 & Born Global \\
\hline Voudouris, Dimitratos \& Salavou & 011 & Born Global \\
\hline Yan \& Panteli & 011 & Born Global \\
\hline Zou \& Ghauri & 010 & Born Global
\end{tabular}

